\title{
BIOEDUSCIENCE
}

ISSN: 2614-1558

\section{The Development of PBL Integrated Bioenvironmentalscience App (BES App) for Environmental Learning}

\author{
Winda Purnama Sari1 ${ }^{*}$, Dwi Indra Aprilliandari1 \\ 1Universitas Muhammadiyah Bangka Belitung, Jl. K.H. Ahmad Dahlan, Pangkalanbaru, Bangka Tengah, Indonesia, 33684
}

*Correspondent Email: winda.purnamasari@unmuhbabel.ac.id

Check for updates

\section{ARTICLE INFO}

\section{Article history}

Received: 01 Nov 2021

Accepted: 24 Nov 2021

Published: 31 Dec 2021

\section{Keyword:}

Bioenvironmentalscience

App (BES App);

PBL;

Environment

m-LMS

Bangka Belitung

\section{Kata kunci:}

Bioenvironmentalscience

App (BES App);

PBL;

Lingkungan;

m-LMS;

Bangka Belitung;

\section{A B S T R A C T}

Background: Biology learning under the Covid-19 pandemic aimed to enhance educators' pedagogical competence by improving thinking abilities and producing results. One of the innovations intended to facilitate environmental learning is the BioEnviroScience App (BES App) for learning environmental science materials, specifically in the sub-environmental changes in the Province of the Bangka Belitung Islands. This media is integrated with Problem Based Learning (PBL) characteristics to guide the learning, allowing students to obtain learning experiences and make learning meaningful. Methods: This development design uses D\&DR, which consists of six stages: 1) identifying the problem, 2) describing the objectives, 3) designing and developing the artefact, 4) testing the artefact, 5) evaluating testing results, and 6) communicating the testing findings. The feasibility test of the produced medium comprises material, biological, and media specialists and is supported by peer review. A questionnaire was used to obtain data, which was examined quantitatively. Results: The material aspect of the feasibility test received $91.08 \%$ in the excellent category, the learning aspect of biology received $85.03 \%$ in the excellent category, and the media aspect received $89.08 \%$ in the excellent category. Conclusion: BES App deserves to be implemented on a large scale in several high schools in Pangkalpinang City.

Pengembangan PBL Integrated Bioenvironmentalscience App (BES App) untuk Pembelajaran Lingkungan

\section{A B S T R A K}

Background: Pembelajaran biologi pasca pandemi Covid-19 mampu mengembangkan kompetensi pedagogi pendidik melalui akselerasi keterampilan berpikir dan menghasilkan sebuah produk. Salah satu inovasi yang dikembangkan untuk memfasilitasi pembelajaran biologi adalah melalui BioEnviroScience App (BES App) untuk pembelajaran materi environmental science khususnya pada sub perubahan lingkungan yang terjadi di Provinsi Kepulauan Bangka Belitung. Media ini mengintegrasikan karakteristik Problem Based Learning (PBL) untuk mengarahkan pembelajaran agar siswa mendapatkan pengalaman belajar dan pembelajaran menjadi bermakna. Metode: desain pengembangan ini menggunakan D\&DR yang terdiri atas enam tahapan yaitu 1) identify the problem; 2) describe the objectives; 3) design and develop the artifact; 4) test the artifact; 5) evaluate testing result; dan 6) communicate the testing result. Pengujian kelayakan media yang dikembangkan melibatkan ahli materi, pembelajaran biologi dan media serta didukung oleh penilaian dari peer assessment. Data dikumpulkan melalui angket dan dianalisis dengan cara deskriptif kuantitatif. Hasil: Hasil uji kelayakan ditinjau pada aspek materi sebesar 91,08\% berkategori sangaat baik, aspek pembelajaran biologi sebesar 85,03\% berkategori sangat baik dan aspek media sebesar $89,08 \%$ berkategori sangat baik. Kesimpulan: BES App layak untuk diimplementasikan dalam skala besar di beberapa SMA Kota Pangkalpinang.

(C) 2021 by authors. License BIOEDUSCIENCE. UHAMKA, Jakarta. This article is open access distributed under the terms and conditions of a Creative Commons Attribution (CC-BY) license.

\section{Introduction}

The characteristics of society in industrial revolution 4.0 include being able to innovate, be creative, utilize technology, PBL, collaborative, lifelong, and student-driven learning. Optimizing the use of technology owned by learning subjects supports the learning process both offline and online. The importance of actualizing conceptual 
understanding through PBL to create solutions to problems is an indication of the achievement of HOTS and skills in the 21st century which include critical thinking, problemsolving, communication, collaboration, and creativity or invention supported by digital literacy skills through ICT (Astuti et al., 2019; Fadel, 2009; Kembara et al., 2019; Sudrajat et al., 2019).

These competencies are needed to prepare students to face global competition. In addition, through the AKM program maps students' minimum competencies in terms of literacy and numeracy, things need to be considered in choosing the accurate techniques, tactics, strategies, approaches, methods, models, teaching materials, and media to support the learning process. KD 3.11 and KD 4.11 for class X high school students listed in Permendikbud No. 37 of 2018 it is known that the minimum cognitive competence that students must achieve is C4 (analysis) and the minimum competence of skills is to formulate ideas for solving problems that occur in the surrounding environment (C6). The minimum competencies expected in the curriculum have reached HOTS as well as students literacy and numeracy skills in biology learning. In addition, it can improve students' problem-solving skills towards the surrounding environment (Sriyati et al., 2021). Achieving these competencies requires learning tools that are relevant to the characteristics of the material and students.

The environmental change material was chosen as the object of research because Bangka Belitung has different characteristics and natural potentials from other regions. One of them is viewed from the mining sector, namely the presence of tin ore, thus stimulating the occurrence of conventional and unconventional mining. This has an impact on the occurrence of land conversion which causes natural damage and natural imbalances. If this happens for a long time, it will cause environmental changes to occur in the Bangka Belitung area.

Based on the results of a survey conducted in January February 2021, it is known that all students in several high schools in Pangkalpinang City already have smartphones to support the learning process, especially during Covid-19. The majority of students use smartphones to carry out social media activities and games. It was judging from the aspect of interest in learning biology, it is known that $85 \%$ of students like learning the field of environmental studies through mobile learning. This is due to the ease of access to study environmental materials, facilitated by teachers and independently. It is viewed from the teacher's perspective, also known that teachers have developed learning tools in the form of teaching materials and media, but not for all the materials developed. The result of the problem identification analysis showed that the teachers have not developed the teaching materials for environmental materials that are relevant to the potential in Bangka Belitung Islands Province yet. While the competencies expected to this learning curriculum will be to provide meaning to students' lives so that the material studied will prioritize the surrounding environment. It is judging from the use of the technology, the majority in learning uses social media, PPT, and video for asynchronous, while for synchronous use zoom meetings or google meet.

Meaningful learning can be obtained if students gain learning experiences and can be relevant to the needs of the surrounding environment so that they can be implemented in everyday life. Meaningful learning is related to the accuracy of implementing teaching strategies that are adapted to the characteristics and willingness of students actively and positively so that learning can be helpful to and students improve learning achievement (Fan et al., 2015).

The learning process is expected to facilitate students in developing thinking skills and producing works. One of the media innovations that can provide a learning experience and make learning meaningful is through the BioEnvironmental Science (BES App) based on a mobileLearning Management System (m-LMS) with a Moodle base and converted into an application (app), making it easier to access on a smartphone. The BES App integrates the PBL presented in the features in the BES App. m-LMS can be accessed easily by learning subjects via smartphones and is quite economical to use (Istanbullu, 2008). The products developed prioritize easy access so that the student can access it through applications or website visits.

This PBL insertion aims to direct learning to achieve the expected competencies. The products developed are expected to provide learning innovations in environmental science materials, especially in the Bangka Belitung area, to achieve the expected competence in the curriculum. The development of this BES App also supports indoor and outdoor learning because it applies the principle of mobile learning, which is used for learning anywhere and anytime. Thus, it is beneficial for students to practice learning outside the classroom. Furthermore, it is critical to developing the BES App because it includes several features such as virtual laboratories and quizzes by presenting questions to stimulate HOTS, literacy, and numeracy for students to support Permendikbud No. 17 of 2021 concerning the National Assessment, which is a form of evaluation of the education system by the Ministry at the primary and secondary education levels. Another feature is to present a form for students to observe in the surrounding environment or learn outside the classroom. Based on the descriptions and characteristics provided above, the goal of developing this BES App media is to assist teachers and students in optimizing the technology available to learning subjects to provide learning experiences, develop thinking skills, and stimulate students' literacy and numeracy abilities. Furthermore, it is expected that it may be utilized as a reference as an 
adaptive biology learning medium in the face of global issues in the future, particularly in the period of the Industrial Revolution 5.0.

\section{Methods}

This research is development research with Design and Development Research model (D\&DR). This development model is a systematic study of the design, development, and evaluation process to build an empirical basis for creating instructional and non-instructional products (Rita C. Richey \& James D. Klein, 2007). This D\&DR model is very relevant to solving problems related to technology (Rita C. Richey \& James D. Klein, 2007; Sahrir et al., 2012). Ken Peffers' development model was used to guide the design and development process in this inquiry (J. Ellis \& Levy, 2010) into six stages which are described in Figure 1 below:

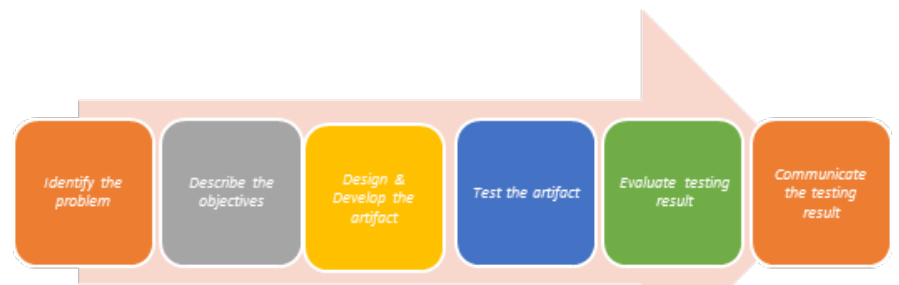

Figure 1. D\&DR development model stages

Figure 1 is the basis for developing product designs in the form of applications that are accessed via smartphones, laptops, or other devices. The BioEnvironmentalScience App (BES App) was developed by integrating the basics of a moodle-based Learning Management System (LMS) was converted into an app through the opening builder application, namely goodbarber. The features presented in the BES App stimulate students to construct thinking skills, literacy, and numeracy skills through observation activities that are studied with the principles of problem based Learning (PBL). The products have been developed and validated by material experts, biologists, and media experts and assessed by peer assessment. The technique of collecting the data used a non-test technique in the form of an assessment questionnaire instrument for the product. The analysis technique used in this research is descriptive quantitative. The feasibility category of the assessment was adopted and modified from (Zunaidah, Farida N. \& Amin, 2016) which is presented in Table 1 below:

Table1. Rating category

\begin{tabular}{cc}
\hline Evaluation & Category \\
\hline $80-100$ & Very feasible \\
$60-79$ & Feasible \\
$40-59$ & Fairly feasible \\
$20-39$ & Less feasible \\
$0-19$ & Not feasible \\
\hline
\end{tabular}

\section{Result}

\section{Identify the problem}

Problem identification is measured from multiple perspectives, including features of technology use, production of instructional materials, contextually examined content, and assessing natural occurrences or phenomena in the Province of the Bangka Belitung Islands or the surrounding environment. Based on the results of a survey conducted in several high schools in Pangkalpinang City in January 2021, it is known that $100 \%$ of students have smartphones. The most frequently downloaded applications include education applications at $12 \%$, games at $9 \%$, and social media at $20 \%$. This result is reinforced by the high percentage of student's interest in studying biology, especially the branch of ecological science digitally, in detail the results of the analysis can be seen in Figure 2 below:

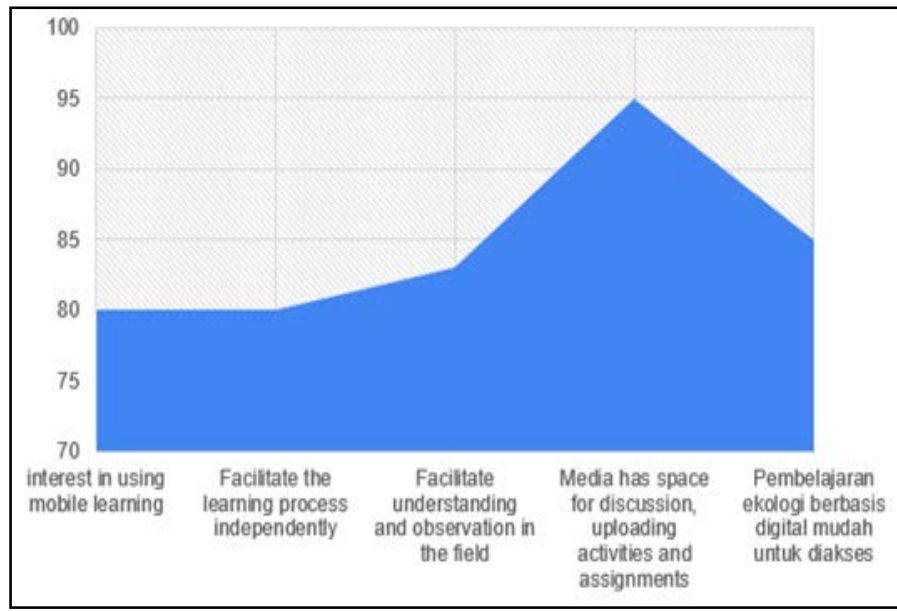

Figure 2. The percentage of students' interest in studying biology digitally

The percentage and students' independent learning activities can be seen in Figure 3 below:

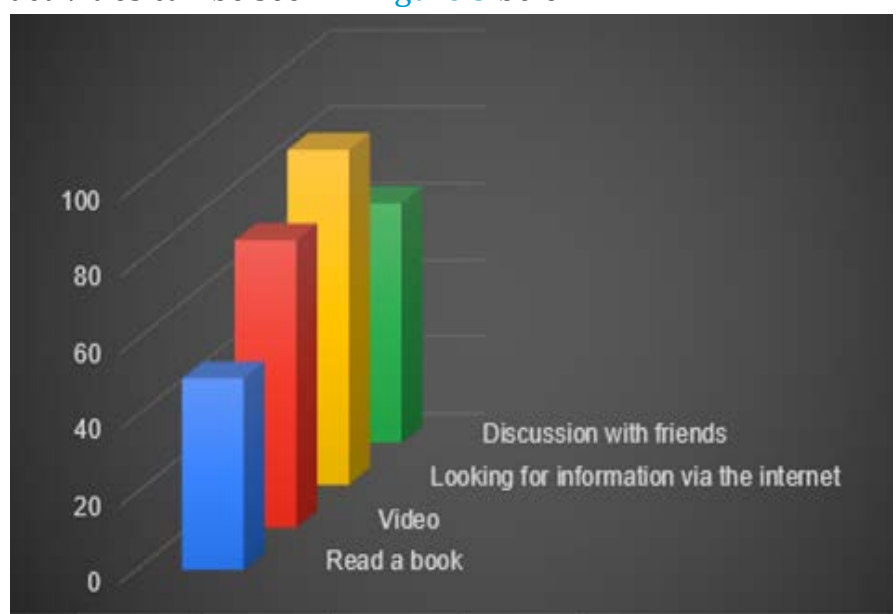

Figure 3. Percentage of students' independent learning activities 

4:

The results of the detailed analysis can be seen in Figure

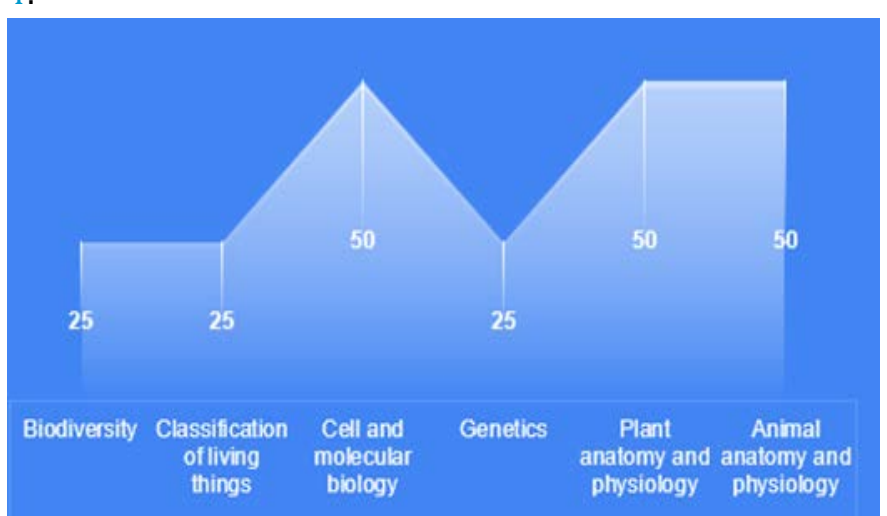

Figure 4. Materials Developed into Teaching Materials and Media

Based on the results of the analysis described above and presented in Figure 4, it is known that the branch of ecology has not been developed in the form of teaching materials or learning media. Characteristics of environmental materials are needed because based on the results of the basic competency review, it is expected that students' analytical skills related to environmental problems in the surrounding environment. It requires learning tools that are relevant to the learning material. It is judging from the survey results, it is known that students' interest in learning in ecological studies can be seen in Figure 5 below:

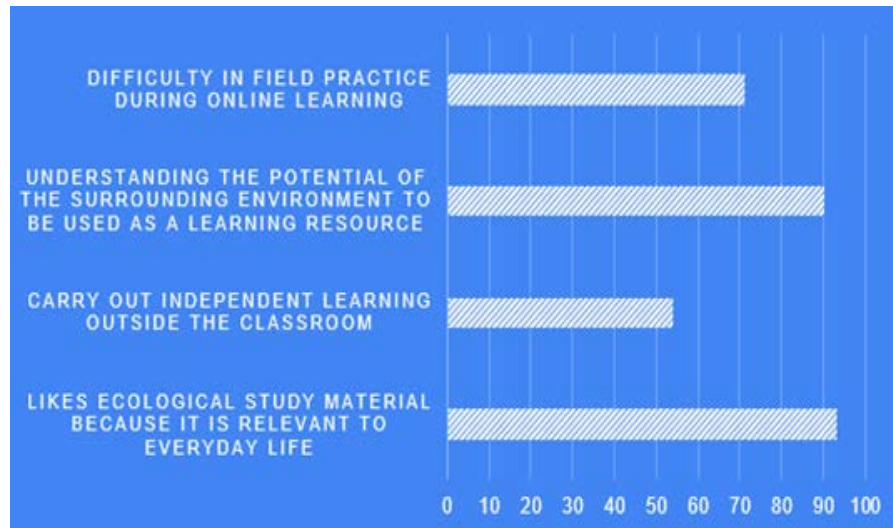

Figure 5. Percentage of students' interest in learning ecology

It is judging from the results of the analysis of Figure 5. It is known that the high interest of students in learning ecology. This is reinforced by the students' analytical skills about the potential of the environment or natural resources in the surrounding surroundings. The results of the mapping based on the analysis of environmental potential or natural resources in the environment around the Bangka Belitung Islands Province carried out by students can be seen in Figure 6 below:

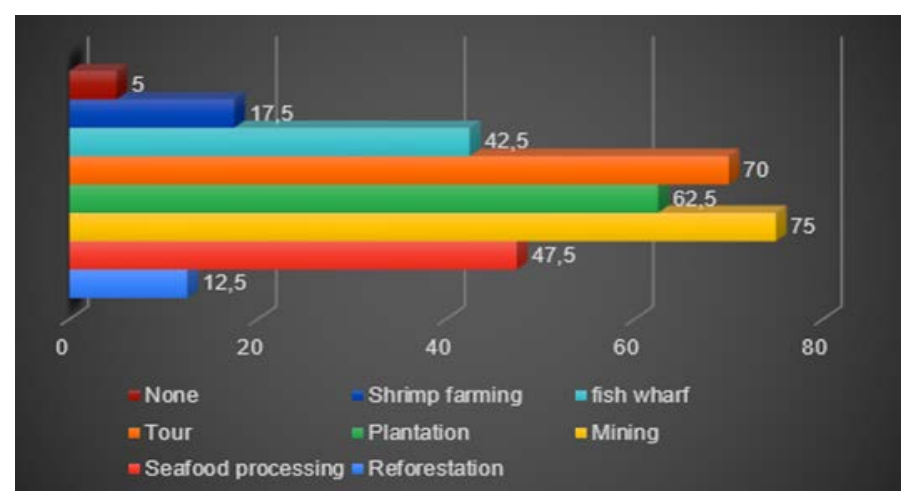

Figure 6. The results of the analysis of the potential of the environment around students

\section{Describe the objectives}

Based on the findings of the problem identification review is vital to create an adaptable and flexible learning media innovation by delivering the characteristics required by students and instructors to support the biology learning process, particularly environmental resources. The developed media is integrated with PBL principles to direct learning. The aim is to facilitate guided and independent learning outside the classroom to be directed. The learning media innovation is in the form of an LMS-based application is packaged in the form of an application to study the surrounding environment.

\section{Design and develop the artefact}

Based on the identification of problems and the purpose of developing innovations in biology learning media, an LMS-based BES application was developed using Moodle and converted into the form of an application. Biology learning using mobile learning can increase teaching effectiveness, form a learning environment that can shape students to be motivated to follow biology learning, and provide challenges and learning experiences to students (Valeeva et al., 2019). Development of applications employing the opening builder, excellent barber. An example of the development of the application process and the results that have developed can be seen in Figure 7 and Figure 8:

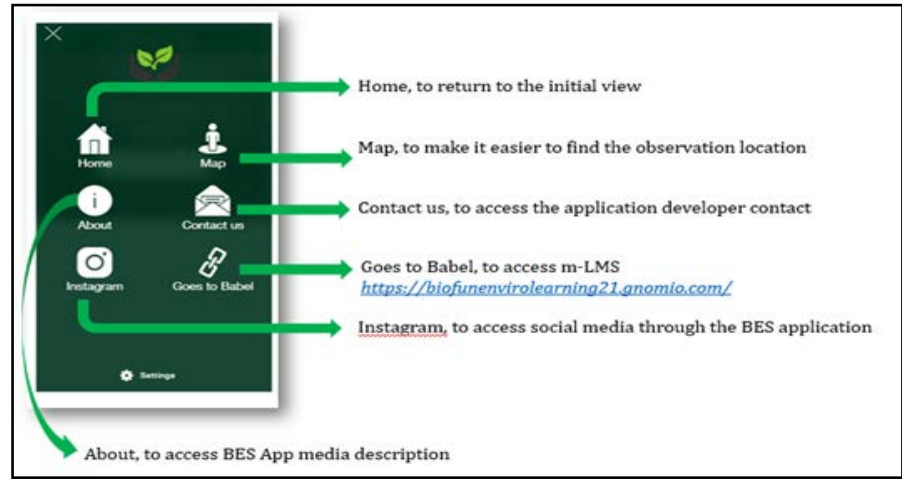

Figure 7. Product feature specifications 


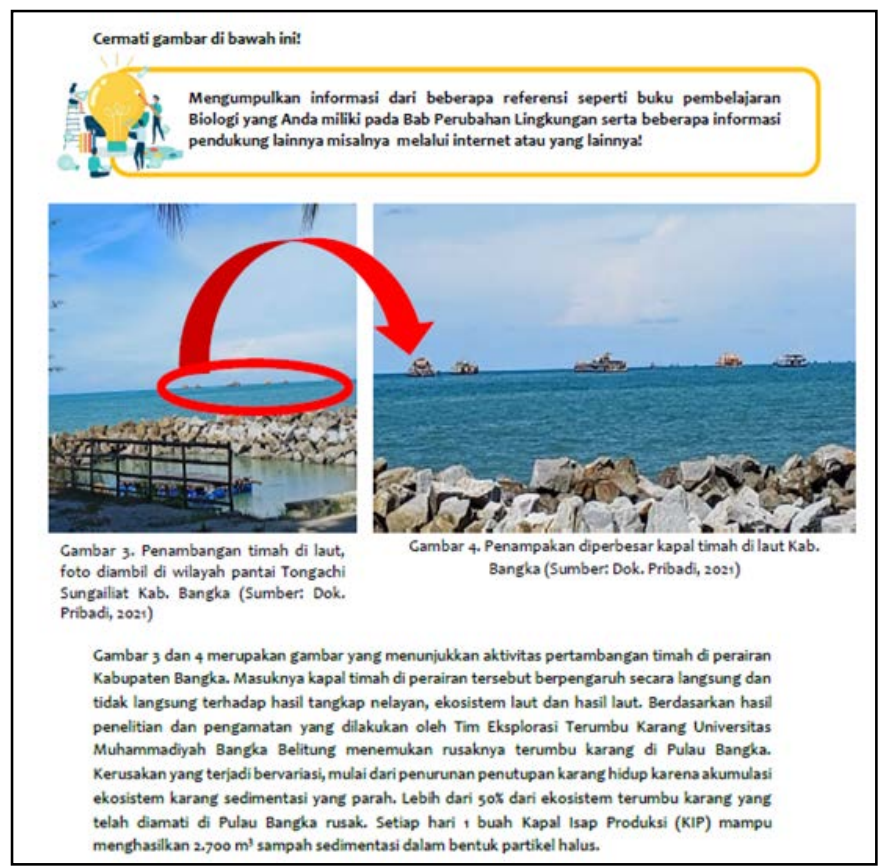

Figure 8. Presentation of questions to stimulate literacy and numeracy skills

\section{Test the artefact}

Expert judgment is used to evaluate the production of BES application in terms of environmental material, biology learning, and media factors. In addition, it is supported by peer assessment or peer assessment related to the developed media. Learning material specialists evaluate the feasibility of media assessment by focusing on someaspects such as material feasibility, material correctness, material presentation, the relevance of facts to ideas, language, and instructional technology experiences. These findings are depicted in Figure 9:

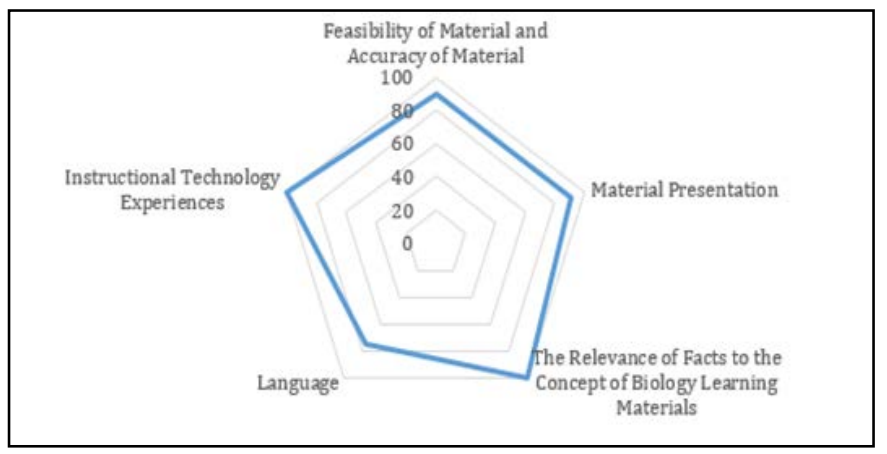

Figure 9. BES application assessment results from material experts

The assessment results were analyzed, and the results can be seen in Figure 10:

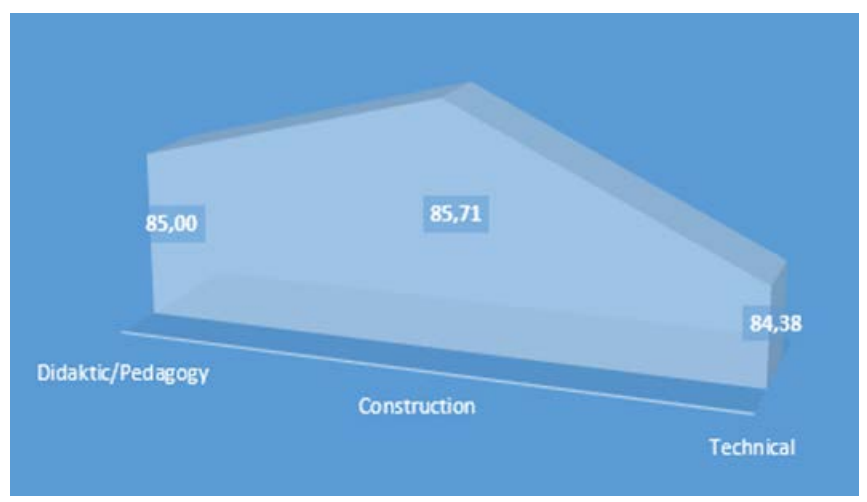

Figure 10. BES App assessment results by learning biologists

The results of the assessment of the BES App by biology learning experts indicate that the application can be used as a supporting tool for the biology learning process. The didactic aspect is visible with the characteristics or principles in the features presented. It includes, for example, observation exercises, thinking skill stimulation, reading and numeracy skill stimulation, and so on. The BES App was evaluated by learning media experts on the components of display and language quality, simplicity of installation, the convenience of operation, dependability, quality of illustrations (pictures, videos, or animations), and ease of use. The assessment results can be seen in Figure 11:

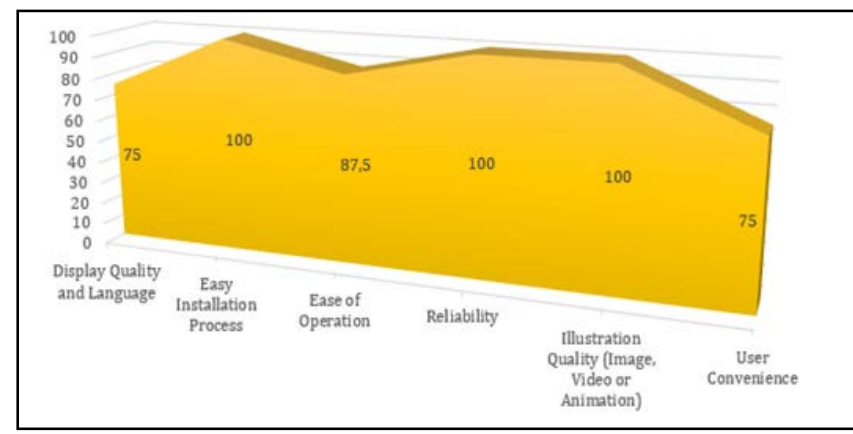

Figure 11. The results of the analysis of the BES App assessment by media experts

The BES App is also evaluated using peer evaluation or peers. Colleagues present an assessment of elements of learning materials, media, and biology learning. The outcomes of the peer review are shown in Table 2 :

Table2. The results of the peer reviewer's assessment of the BES App in terms of media, material, and biology learning aspects

\begin{tabular}{llr}
\hline Aspect & Rating Indicator & Percentage \\
\hline \multirow{3}{*}{ Media } & Display Quality and & \\
& Language & 85,00 \\
& Easy Installation & \\
& Process & 100,00 \\
& Ease of Operation & 87,50 \\
& Reliability & 100,00 \\
& Illustration Quality & \\
& (Picture, Video or & \\
& Animation) & 100,00
\end{tabular}




\begin{tabular}{llr}
\hline Aspect & Rating Indicator & Percentage \\
\hline \multirow{4}{*}{ Material } & User convenience & 75,00 \\
& Feasible and Accuracy & \\
& of the Material & 95,00 \\
& Material presentation & 92,31 \\
& The Relevance of Facts & \\
& to the Concept of & \\
& Biology Learning & \\
& Materials & 100,00 \\
& Language & 75,00 \\
& Instructional Technology & \\
& Experiences & 100,00 \\
Biology Learning & Didactic & 89,50 \\
& Construction & 84,38 \\
\hline
\end{tabular}

\section{Evaluate testing result}

Based on the findings of the evaluations offered by material experts, biology learning specialists, media, and colleagues, it is clear that certain aspects need to be addressed. Figure 12 depicts these sections:

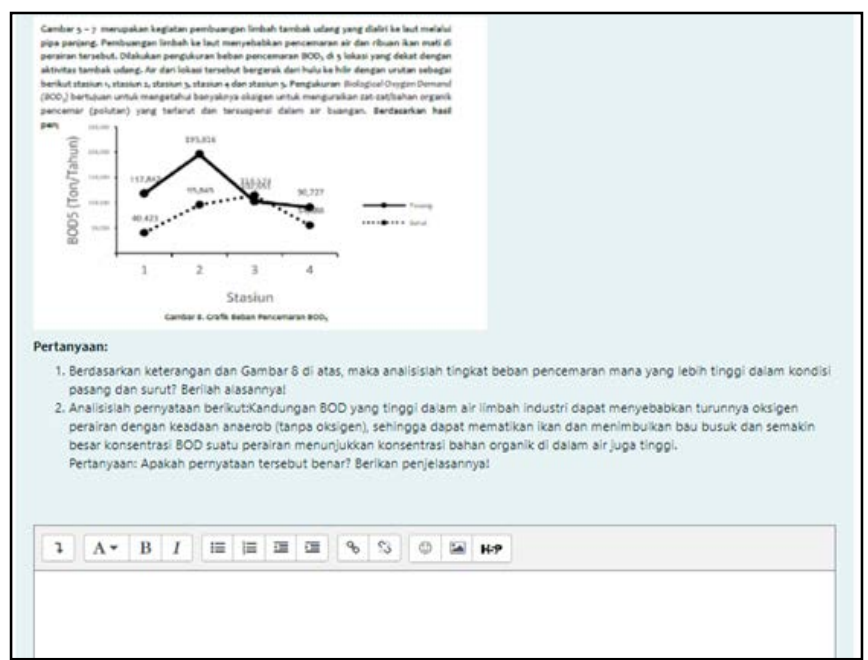

Figure 12. Examples of literacy and numeracy-based questions

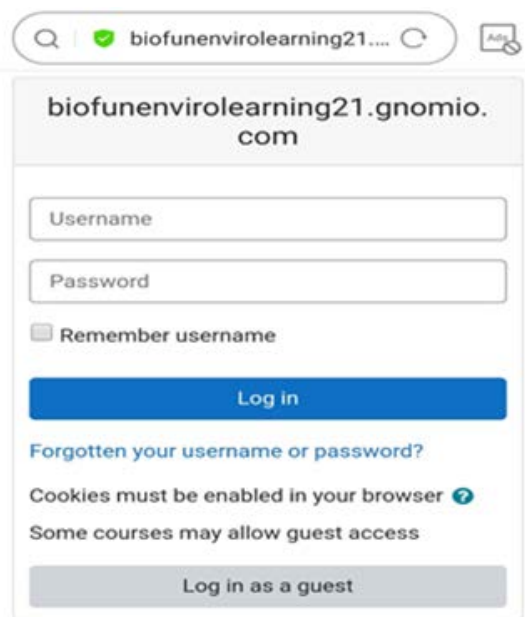

Figure 13. Revised user login display to identify students accessing learning

\section{Communicate the testing result}

This application is transmitted in the form of large-scale testing at numerous high schools in Pangkalpinang City, and if there are suggestions, changes to the product are made. As a result, it is expected that this medium will be employed in various regions within the Province of the Bangka Belitung Islands.

\section{Discussion}

The analysis results given in Figure 2 are compatible with the optimization of the technology utilized by instructors to enhance biology learning. Based on the results of the analysis of interviews and questionnaires given to high school biology teachers in Pangkalpinang City known that $75 \%$ of teachers are interested in optimizing the use of technology as a supporter of learning in the field of ecology because it provides new learning experiences for learning subjects. In addition, it can provide easy access for students during learning outside the classroom and assist teachers in monitoring student activities, either in the form of digital reporting or other forms of activity. Digital-based learning can also stimulate students in independent learning.

According to material expert guidance, the material relevant to the application being built is to offer a concept map at the beginning of the e-LKS presentation, delivered as a pdf file. Based on the results of the assessment of the biology learning expert, it was reviewed on the didactic, construction, and technical aspects. Several components in the didactic aspect show the existence of learning activities through observation skills as one of the science process skills that students must have in studying biology (Sahnaz et al., 2018), practice problem-solving skills, identify problems, plan, implement and evaluate (Fitriani et al., 2019). Various studies are relevant to survey the perspectives of students and teachers regarding learning in the Covid-19 era by focusing on online learning, digital strategies, artificial intelligence, social interaction, technology, and strategies used to balance theory with practice (Dwivedi et al., 2020).

The student self-learning activities presented in Figure 3 above are relevant to the learning model and the method chosen by the teacher in learning biology. Based on the survey results, it is known that the learning models used to study biology include $25 \%$ inquiry, discovery 25 , problembased learning (PBL) 75\%, and project-based learning (PBL) 50\%. The implementation of this learning model includes numerous techniques that assist learning and are based on the analysis findings. It is known that the bulk of the methods employed by instructors, with a proportion of 87.5 per cent, are conversations. Question and response are employed $75 \%$ of the time, lecture $50 \%$ of the time, observation 62.5 per cent of the time, and demonstration 37.5 per cent of the time. The demand for biological 
learning aids, such as teaching materials, has grown, but not for learning media. During Covid-19, the majority of online learning employs many supporting tools, including Google Classroom (25\%), the internet (6\%), textbooks (4\%), and PPT and modules (3\%). According to the material created into teaching materials, it is still confined to these features.

m-LMS can increase literacy, and in general, user feedback indicates that this product is suitable for use as a learning medium (Riyana, 2018). Practice outside the classroom can help kids enhance their cognitive abilities (Lai et al., 2015). The production of relevant LMS is utilized for natural science learning by representing phenomena, stimulating experimental research, and building models with problem-solving applications (Cavus \& Alhih, 2015). $\mathrm{m}$-LMS at the higher education level is a tool that can help to learn and affect learning achievement through several features presented in the LMS such as lecture notes, ebooks, assignments, and quizzes (Kulshrestha, 2013; Shin \& Kang, 2015). The use of mobile learning in learning can increase students' motivation to learn biology and improve teachers' pedagogical abilities to facilitate learning through technology (Alfiana Monika Sari \& Heru Nurcahyo, 2018; Montrieux et al., 2015). The development of m-LMS leads to transforming the learning process in conventional classrooms into mobile learning from network groups with collaborative learning that enables online and offline learning activities everywhere and at any time (Hemabala, 2012).

The insertion of PBL principles in m-LMS is positions students as the center of learning (Moore, 2011) through presenting authentic and meaningful situations to students that can become the basis for investigation and inquiry. The characteristics of PBL are that there are driving questions or problems, interdisciplinary focus, authentic investigation, production of artifacts and displays, and collaboration. The problem studied should be a contextual problem found by students in their daily life. These problems can be reduced by combining many concepts and principles with the learning curriculum being studied (Arends, 2012). PBL is effective for increasing sustainable environmental literacy (L.K. Febriasari \& N Supriatna, 2017) and can help increase vocabulary about the environment and writing skills significantly (Iswandari, Dyah Christina, 2017). Furthermore, PBL is thought to be utilized to improve kids' inquiry abilities via their syntax (Riyanto, 2016). PBL facilitates students to develop independent and collaborative or cooperative skills through activities (Sukmawati \& Permadani, 2017) which are described in the PBL syntax.

The presentation of quiz questions that lead to literacy and numeracy skills aims to overcome the low level of student scientific literacy due to incorrect selection of textbooks, misconceptions, and non-contextual learning
(Fuadi et al., 2020). The implementation of the national assessment is based on mapping and improving the quality of education as a whole (Rohim et al., 2021).

\section{Conclusion}

The creation of the BES App is, combined with PBL for studying environmental science sub-specific environmental change, is possible for widespread usage in numerous high schools in Pangkalpinang City. The findings of the feasibility test were examined on the material aspect, which received 91.08 per cent in the excellent category, the biology learning element, which received 85.03 per cent in the excellent category, and the media aspect, which received 89.08 per cent in the excellent category.

\section{Acknowledgement}

Thank you to the Institute for Research and Community Service (LPPM) Universitas Muhammadiyah Bangka Belitung and Research and Technology-BRIN for the opportunity to develop products as a form of contribution given by the institution to the field of education and learning, especially for the Bangka Belitung Islands Province.

\section{Declaration statement}

The authors reported no potential conflict of interest.

\section{References}

Alfiana Monika Sari \& Heru Nurcahyo. (2018). Improving Students Learning Motivation Through Mobile Learning. Jurnal Pendidikan Biologi Indonesia, 4(3), 271-276.

Arends, R. L. (2012). Learning to Teach (9th ed.). Mc Graw Hill.

Astuti, A. P., Aziz, A., Sumarti, S. S., \& Bharati, D. A. L. (2019). Preparing 21st Century Teachers: Implementation of 4C Character's Pre-Service Teacher through Teaching Practice. Journal of Physics: Conference Series, 1233(1), 1-8. https://doi.org/10.1088/1742-6596/1233/1/012109

Cavus, N., \& Alhih, M. S. (2015). Learning Management Systems Use in Science Education. Procedia - Social and Behavioral Sciences, 143(December), 517-520 https://doi.org/10.1016/j.sbspro.2014.07.429

Dwivedi, Y. K., Hughes, D. L., Coombs, C., Constantiou, I., Duan, Y., Edwards, J. S., Gupta, B., Lal, B., Misra, S., Prashant, P., Raman, R., Rana, N. P., Sharma, S. K., \& Upadhyay, N. (2020). Impact of COVID-19 pandemic on information management research and practice: Transforming education, work and life. International Journal of Information Management, 55(July), 102211. https://doi.org/10.1016/j.ijinfomgt.2020.102211

Fadel, B. T. \& C. (2009). 21st Century Skills Learning for Life in Our Times (First Edit). Jossey-Bass A Wile Imprint.

Fan, K. K., Xiao, P. wei, \& Su, C. H. (2015). The effects of learning styles and meaningful learning on the learning achievement of gamification health education curriculum. Eurasia Journal of Mathematics, Science and Technology Education, 11(5), 1211-1229. https://doi.org/10.12973/eurasia.2015.1413a

Fitriani, A., Zubaidah, S., Susilo, H., \& Irawati Al Muhdhar, M. H. 
(2019). The integrated problem based learning and predict, observe, explain (PBL-POE) to empower students' problemsolving skills. ACM International Conference Proceeding Series, June 2020, 375-379. https://doi.org/10.1145/3345120.3345139

Fuadi, H., Robbia, A. Z., Jamaluddin, J., \& Jufri, A. W. (2020). Analisis Faktor Penyebab Rendahnya Kemampuan Literasi Sains Peserta Didik. Jurnal Ilmiah Profesi Pendidikan, 5(2), 108-116. https://doi.org/10.29303/jipp.v5i2.122

Hemabala, J. \& E. S. M. S. (2012). The Frame Work Design Of Mobile Learning Management System. International Journal of Computer and Information Technology, 01(02), 179-184.

Istanbullu, A. (2008). Mobilim: Mobile learning management framework system for engineering education. International Journal of Engineering Education, 24(1), 32-39.

Iswandari, Dyah Christina, J. A. P. \& B. Y. C. (2017). Effect of Environmental Problem-based Learning on the Indonesian EFL Students ' Environment - related Vocabulary Mastery and Writing Ability. Theory and Practice in Language Studies, 7(8), 608-616.

J. Ellis, T., \& Levy, Y. (2010). A Guide for Novice Researchers: Design and Development Research Methods. Proceedings of the 2010 InSITE Conference, 107-118. https://doi.org/10.28945/1237

Kembara, M., Rozak, R. W., \& Hadian, V. A. (2019). Research-based Lectures to Improve Students' 4C (Communication, Collaboration, Critical Thinking, and Creativity) Skills. Advances in Social Science, Education and Humanities Research. INternational Symposium on Social Sciences, Education, and Humanities (ISSEH), August, 22-26. https://doi.org/10.2991/icollite-18.2019.50

Kulshrestha, T. \& A. R. K. (2013). Benefits of Learning Management System ( LMS ) in Indian Education. International Journal Oof Computer Science \& Engineering Technology (IJCSET), 4(08), 1153-1164.

L.K. Febriasari \& N Supriatna. (2017). Enhance Environmental Literacy through Problem Based Learning. International Conference on Mathematics and Science Education (ICMSCE). https://doi.org/10.1088/1742-6596/895/1/012163

Lai, A. F., Lai, H. Y., Chuang, W. H., \& Wu, Z. H. (2015). Developing a mobile learning management system for outdoors nature science activities based on 5E learning cycle. Proceedings of the International Conference on E-Learning 2015, ELEARNING 2015 - Part of the Multi Conference on Computer Science and Information Systems 2015, 2002, 59-65.

Montrieux, H., Vanderlinde, R., Schellens, T., \& Marez, L. De. (2015). Teaching and Learning with Mobile Technology: A Qualitative Explorative Study about the Introduction of Tablet Devices in Secondary Education. Journal Plos One, 10(12),

$1-17$. https://doi.org/10.1371/journal.pone.0144008

Moore, T. B. \& S. (2011). New Approaches to Problem Based Learning Revitalizing Your Practice in Higher Education. Routledge Tylor \& Francis Group.

Rita C. Richey \& James D. Klein. (2007). Design and Development Research. Lawrence Erlbaum Associates.

Riyana, C. (2018). Developing Mobile Learning Management System (Mlms) Based on Android for Curriculum Literacy. Edulib $8(2)$

222 https://doi.org/10.17509/edulib.v8i2.13599

Riyanto, D. A. dan. (2016). A Problem-Based Learning Model In
Biology Education Courses To Develop Inquiry Teaching Competency of Preservice Teachers Diah Aryulina Dan Riyanto Model Pembelajaran Berbasis Masalah. Cakrawala Pendidikan, 2, 47-57.

Rohim, D. C., Rahmawati, S., \& Ganestri, I. D. (2021). Konsep Asesmen Kompetensi Minimum Meningkatkan Kemampuan Literasi Numerasi Sekolah Dasar untuk Siswa. Jurnal Varidika, 33(1), 54-62. https://doi.org/10.23917/varidika.v33i1.14993

Sahnaz, S., Harlita, H., \& Ramli, M. (2018). Improving Observing Skills of High School Students through Guided Inquiry Model. International Journal of Pedagogy and Teacher Education, 2(1), 53 https://doi.org/10.20961/ijpte.v2i1.16608

Sahrir, M. S., Alias, N. A., Ismail, Z., \& Osman, N. (2012). Employing design and development research (DDR) approaches in the design and development of online arabic vocabulary learning games prototype. Turkish Online Journal of Educational Technology, 11(2), 108-119.

Shin, W. S., \& Kang, M. (2015). The Use of a Mobile Learning Management System at an Online University and Its Effect on Learning Satisfaction and Achievement. International Review of Research in Open and Distributed Learning, 16(3), 110-130.

Sriyati, S., Septiani, F., Sera, K., \& Udayani, H. (2021). Local wisdom-based teaching materials to improve student problem-solving. 9(2), 111-123.

Sudrajat, A. K., Susilo, H., \& Indriwati, S. E. (2019). Application of Learning Based on Problem through Lesson Study in Learning Biology in 21st Century Course for Developing Biology Students Critical Thinking Skills and Collaboration Ability. ICLI 2018 - 2nd International Conference on Learning Innovation, November 2019, 145-152. https://doi.org/10.5220/0008409101450152

Sukmawati, I., \& Permadani, K. G. (2017). Jurnal Pendidikan Biologi. Jurnal Pendidikan Biologi, 7(2), 108-116.

Valeeva, N. G., Pavlova, E. B., \& Zakirova, Y. L. (2019). M-learning in teaching ESP: Case study of ecology students. European Journal of Contemporary Education, 8(4), 920-930. https://doi.org/10.13187/ejced.2019.4.920

Zunaidah, Farida N. \& Amin, M. (2016). Pengembangan Bahan Ajar Matakuliah Bioteknologi Berdasarkan Kebutuhan Dan Karakter Mahasiswa Universitas Nusantara Pgri Kediri. Jurnal Pendidikan Biologi Indonesia, 2(1), 19-30. 